\title{
Комбіноване застосування кріохірургічного методу та хімічної деструкціі в комплексному лікуванні пацієнтів з вогнищевою патологією печінки
}

\author{
О. І. Дронов ${ }^{1,2}$, І. О. Ковальська ${ }^{1,2}$, Є. С. Козачук ${ }^{1}$, Д. І. Хоменко ${ }^{1}$, П. П. Бакунець² \\ ${ }^{1}$ Національний медичний університет імені О. О. Богомольця, м. Київ, \\ ${ }^{2}$ Київський міський центр хірургії захворювань печінки, жовчних шляхів та підшлункової залози імені В. С. Земскова

\section{Combined application of cryosurgical method and chemical destruction in complex treatment of patients with focal hepatic pathology}

\author{
O. I. Dronov ${ }^{1,2}$, I. O. Kovalska ${ }^{1,2}$, Ye. S. Kozachuk ${ }^{1}$, D. I. Khomenko ${ }^{1}$, P. P. Bakunets ${ }^{2}$ \\ ${ }^{1}$ Bogomolets National Medical University, Kyiv, \\ ${ }^{2}$ Kyiv's Municipal Centre of Surgery of the Diseases of liver, Biliary Ducts and Pancreatic Gland named after Zemskov
}

\begin{abstract}
Peферат
Мета. Оцінити ефективність комбінованого застосування кріохірургічного методу та хімічної деструкції 10\% розчином кальцію хлориду в комплексному лікуванні пацієнтів з вогнищевою патологією печінки (ВПП).

Матеріали і методи. Проаналізовано результати застосування локальних методів деструкції у складі комплексного лікування 316 пацієнтів з ВПП.

Результати. Між досліджуваними групами пацієнтів за частотою, структурою, ступенем тяжкості специфічних ускладнень, летальністю достовірної різниці не виявлено ( $>$ 0,05). Після комбінованого застосування кріохірургічного методу та хімічної деструкції достовірно збільшилась частота повних та часткових відповідей пухлинних вогнищ на лікування, зменшилася частота стабілізації і прогресування процесу ( $<<0,05)$, локальних рецидивів та збільшилася частота конверсії до резектабельності ( $<$ < 0,05).

Висновки. Комбіноване застосування кріодеструкції та хімічної абляції є безпечним та ефективним методом, який дає змогу достовірно покращити результати лікування паціентів з ВПП.

Ключові слова: кріохірургічний метод; кріодеструкція; хімічна деструкція; 10\% розчин кальцію хлориду; вогнищева патологія печінки.

Abstract

Objective. To estimate the efficacy of combined application of cryosurgical method and chemical destruction, using $10 \%$ solution of calcium chloride in complex treatment of patients, suffering focal hepatic pathology (FHP)

Materials and methods. Results of application of local methods of destruction in a content of complex treatment of 316 patients with FHP were analyzed.

Results. Trustworthy difference between the groups of the patients investigated in accordance to rate, structure, severity of specific complications, lethality was not revealed ( $p>0.05$ ). After combined application of cryosurgical method and chemical destruction the rate of complete and partial answers of tumoral foci towards the treatment have been trustworthily enhanced, the rate of local recurrence, the process stabilization and progress - diminished $(p<0.05)$, and the rate of conversion towards resectability enhanced $(\mathrm{p}<0.05)$.

Conclusion. Combined application of cryodestruction and chemical ablation constitutes a secure and effective method, which give possibility to improve the results of treatment in patients with FHP trustworthily.

Keywords: cryosurgical method; cryodestruction; chemical destruction; 10\% solution of calcium chloride; focal hepatic pathology
\end{abstract}

За останні десятиліття почастішало виявлення ВПП злоякісного генезу, що можна пов'язати з доступністю та широким використанням у клінічній практиці неінвазивних методів візуалізації, таких як ультразвукове дослідження (УЗД), комп'ютерна томографія (КТ), магнітно-резонансна томографія (МРТ) тощо [1, 2]. Незважаючи на успіхи сучасної інструментальної діагностики, близько 80\% хворих з ВПП, які вперше звернулися за медичною допомогою, не підлягають радикальному лікуванню. У зв’язку з цим останнім часом набувають розвитку локальні методи деструкції, серед яких кріохірургічний метод вважається одним із найперспективніших [3]. Однак застосу- вання кріохірургічного методу в лікуванні ВПП злоякісного генезу в деякій мірі обмежене через неможливість досягти тотальної деструкції пухлинного вогнища. Цим зумовлені спроби його удосконалення шляхом потенціювання циторедуктивного впливу наднизьких температур [4 - 7]. На наш погляд, перспективною є розробка способів підвищення радикальності кріохірургічного методу шляхом поєднання дії наднизьких температур та хімічних агентів зі збереженням усіх переваг застосування наднизьких температур.

Мета дослідження: оцінити ефективність комбінованого застосування кріохірургічного методу та хімічної де- 
струкції 10\% розчином кальцію хлориду в комплексному лікуванні пацієнтів з ВПП.

\section{Матеріали і методи дослідження}

Проаналізовано результати застосування локальних методів деструкції у 316 хворих з ВПП у складі комплексного лікування, проведеного на базі Київського міського центру хірургії захворювань печінки, жовчних шляхів та підшлункової залози імені В. С. Земскова в період з 2006 по 2017 р. Пацієнтів методом рандомізації було розподілено на дві групи: 1-ша група (порівняльна) - 234 пацієнти, яким виконано кріодеструкцію ВПП у складі комплексної програми лікування, 2-га група - 82 пацієнти, яким застосували комбінацію кріодеструкції та хімічної деструкції ВПП у складі комплексної програми лікування.

Досліджувані групи пацієнтів не відрізнялись за віком, статтю, генезисом ВПП, локалізацією первинних пухлин, строками виникнення метастазів, локалізацією, кількістю та розмірами пухлинних вогнищ, видами виконаних основних оперативних втручань.

Критеріӥ включення хвориху дослідження: морфологічно верифікована злоякісна ВПП; резектабельність (R0) первинної пухлини у разі синхронного метастатичного ураження печінки; загальний стан хворих, оцінений за шкалою ECOG (Eastern Cooperative Oncology Group) не більш як у 2 бали; вік старше 18 років; згода хворих на проведення лікування і амбулаторного моніторингу.

Критеріӥ виключення хворих із дослідження: наявність віддалених позапечінкових метастазів, асциту, канцероматозу, плевриту, гострої хірургічної патології як ускладнення основного захворювання, декомпенсованої печінкової недостатності (клас С за Чайлдом-П'ю), загальносоматичних захворювань у стадії декомпенсації, IV клінічна група, відмова пацієнта від участі в дослідженні на будь-якому з етапів, неможливість проведення амбулаторного моніторингу.

Передопераційне обстеження проводили згідно з прийнятими стандартами. 3 метою прогнозування виникнення гострої печінкової недостатності в післяопераційному періоді стандартне обстеження доповнювали визначенням співвідношення залишкового обсягу печінки до маси тіла, планованого залишкового обсягу печінки (FLR) i функціонального стану печінки.

Тактику лікування хворих визначали після обговорення на мультидисциплінарному консиліумі на підставі результатів передопераційного обстеження згідно з прийнятими в Україні стандартами лікування онкологічних хворих, рекомендацій ESMO (European Society for Medical Oncology) i EASL-EORTC (European Association for the Study of the Liver - European Organisation for Research and Treatment of Cancer).

Усі пацієнти були прооперовані через відкритий лапаротомний доступ під загальним знеболюванням.

Показаннями до застосування локальних методів деструкції були: злоякісна ВПП центральної локалізації з інвазією магістральних судинних структур і жовчних проток, яка не підлягала радикальному хірургічному лікуванню; множинне білобарне ураження печінки, яке не перевищувало 80\% іiі об'єму; наявність вогнищевого ураження контрлатеральної частки печінки, яке залишалося після резекції; важкодоступне для резекції розташування вогнища; наявність загальносоматичних протипоказань до резекції або недостатність функціональних резервів печінки за наявності фонової патології відмова пацієнта від виконання резекції печінки за наявності резектабельного процесу в печінці.

Локальні методи деструкції застосовували з метою повної ліквідації або зменшення обсягу пухлинних вогнищ 3 їх конверсією в резектабельний стан, підвищення абластичності оперативного втручання і профілактики рецидивів.

Використовували такі методики локальної деструкції: кріодеструкція/кріохімічна деструкція як самостійний метод; резекція печінки та кріодеструкція/кріохімічна деструкція резидуальних пухлинних вогнищ.

Анатомічну резекцію печінки виконували згідно з класифікацією Brisbane 2000 р. IHPBA (International HepatoPancreato-Biliary Association).

Методика комбінованої кріодеструкцї та хімічної деструкції. Спочатку виконували хімічну деструкцію вогнища шляхом інтратуморальної ін'єкції 10\% розчину кальцію хлориду і через 5 хв після закінчення введення виконували кріодеструкцію.

Інтратуморальне введення 10\% розчину кальцію хлориду здійснювали повільно впродовж 5 хв шляхом обколювання пухлинного вузла, інфільтруючи тканини пухлини від поверхні вглиб пухлинного вогнища. Дозу препарату розраховували за формулою, прийнятою для розрахунку дози 96\% розчину етанолу для алкоголізації пухлин печінки:

$$
\mathrm{V}=4 / 3 \pi(\mathrm{r}+0,5)^{3}
$$

де: $\mathrm{V}$ - доза препарату, що вводиться (мл); $\mathrm{r}$ - радіус вогнища в найбільшому вимірі (см); 0,5 - коефіцієнт для більшої радикальності ефекту.

Кріохірургічну деструкцію виконували з використанням кріогенної установки "Кріо-Пульс" (рідкий азот). Застосовували подвійний кріоцикл зі спонтанним таненням. Час експозиції заморожування становив 10 - 20 хв у залежності від діаметра вогнища.

Обов'язковою умовою дослідження було проведення системної поліхіміотерапії (ПХТ) на підставі морфологічного типу пухлинного ураження, стадії і термінів виникнення метастазів.

Завершували дослідження визначенням частоти, структури і тяжкості післяопераційних ускладнень, післяопераційної летальності, відповіді ВПП на лікування, конверсії пухлини в резектабельний стан, частоти локального рецидиву.

Ускладнення і летальність оцінювали в строки до 30 діб після операціі. Ступінь тяжкості ускладнень визначали за класифікацією Clavien-Dindo.

Відповідь пухлинних вогнищ печінки оцінювали через 3 міс від початку лікування згідно з критеріями RECIST 1.1 (2008) на підставі даних МРТ.

Амбулаторний моніторинг за ефективністю лікування проводили кожні 3 міс перші 2 роки і кожні 6 міс наступні 3 роки на підставі даних клінічного, лабораторного обстеження, результатів УЗД і МРТ. 


\begin{tabular}{|c|c|c|c|c|c|}
\hline \multicolumn{6}{|c|}{ Характеристика післяопераційних специфічних ускладнень у досліджуваних групах хворих } \\
\hline \multirow{3}{*}{ Ускладнення } & \multicolumn{4}{|c|}{ Група хворих } & \multirow{3}{*}{$\mathrm{p}$} \\
\hline & \multicolumn{2}{|c|}{ 1-ша $(n=234)$} & \multicolumn{2}{|c|}{2 -га $(n=82)$} & \\
\hline & абс. & $\%$ & абс. & $\%$ & \\
\hline Біліоми & 9 & 3,8 & 4 & 4,9 & 0,09 \\
\hline Внутрішньочеревна кровотеча & 4 & 1,7 & 3 & 3,7 & 0,16 \\
\hline Біліарні нориці & 3 & 1,3 & 4 & 4,9 & 0,54 \\
\hline Плевральний випіт & 17 & 7,3 & 8 & 9,7 & 0,61 \\
\hline Підвищення рівня печінкових ферментів & 19 & 8,1 & 9 & 11,0 & 0,32 \\
\hline
\end{tabular}

\section{Результати}

Частота специфічних післяопераційних ускладнень у 1-й групі становила 5,9\%, у 2-й - 7,3\%. У окремих хворих спостерігали більше одного ускладнення. У структурі специфічних ускладнень переважали підвищення рівня печінкових ферментів, плевральний випіт, біліоми, гематоми, внутрішньочеревна кровотеча, біліарні нориці (див. таблищю). У жодного пацієнта гострої печінкової недостатності та кріогенного шоку не спостерігали. Тяжкість специфічних ускладнень за класифікацією Clavien-Dindo відповідала I-II ступеню у 87,4\% пацієнтів 1-ї групи та у 79,9\% пацієнтів 2-ї групи (p = 0,13), III-IV - у 12,6 та 20,1\% пацієнтів відповідно ( $\mathrm{p}=0,07)$.

У 1-й групі померли 12 хворих, післяопераційна летальність становила 5,1\%, у 2-й групі - 3 (3,7\%) хворих. Причини смерті не були пов'язані з кріодеструкцією.

Результати застосування локальних методів деструкції у 1-й та 2-й групах хворих, оцінені відповідно до критеpіïв RECIST 1.1 (2008), були такими: частота повних відповідей ВПП на лікування становила 32,6 і 54,8\% (p=0,031), часткових - 39,8 і 69,6\% (p=0,014), стабілізації процесу 16,3 i 7,4\% (p=0,09), прогресування - 4,6 i 1,1\% (p=0,06) відповідно. Показники розраховували від загальної кількості вогнищ у групі, які піддавали деструкції. Локальний рецидив виник у 27 (11,5\%) хворих $1-\ddot{і}$ групи і у $5(6,1 \%)-2-і$ групи $(\mathrm{p}=0,04)$. Вдалося досягти конверсії пухлин до резектабельного стану у 31 (32,9\%) із 94 хворих із первинно нерезектабельним ураженням печінки $1-і ̈$ групи та у $16(51,6 \%)$ із 31 хворого $2-і ̈$ групи $(\mathrm{p}=0,07)$.

\section{Обговорення}

Проведений статистичний аналіз показав, що між досліджуваними групами пацієнтів за частотою, структурою, ступенем тяжкості специфічних ускладнень та післяопераційною летальністю достовірної різниці не було ( $>$ > 0,05). У 2-й групі хворих, яким застосовували комбінацію кріодеструкції та хімічної деструкції 10\% розчином кальцію хлориду, спостерігали статистично значуще збільшення частоти повних та часткових відповідей пухлинних вогнищ на лікування та зменшення частоти стабілізації і прогресування процесу порівняно з 1-ю групою $(\mathrm{p}<0,05)$. Частота локальних рецидивів також була статистично меншою у $2-$ й групі порівняно з 1 -ю $(\mathrm{p}<0,05)$. Після застосування комбінації кріодеструкції та інтратуморального введення 10\% розчину кальцію хлориду частота конверсії пухлин до резектабельного стану була достовірно більшою, ніж після застосування лише кріодеструкції - відповідно 51,6 та 32,9\% (p < 0,05).

\section{Висновки}

Комбіноване застосування кріодеструкції та хімічної абляції є безпечним та ефективним методом, який дає змогу достовірно покращити результати лікування пацієнтів з ВПП.

\section{References}

1. Shalimov SO, Lytvynenko OO, Myacoyedov DV, Yevtushenko OI. Kriokhirurhiia orhaniv travlennia. Kyiv: Chetverta khvylia; 2006. $108 \mathrm{p}$. [In Ukrainian].

2. Smirnov LYu. Metody likuvannia nerezektabelnykh metastaziv zloiakisnykh pukhlyn u pechintsi. Zaporozhskyi medytsynskyi zhurnal. 2009;11(3): 67-71. [In Ukrainian].

3. He L, Niu L, Korpan NN, Sumida S, Xiao Y, Li J, et al. Clinical Practice Guidelines for Cryosurgery of Pancreatic Cancer: A Consensus Statement From the China Cooperative Group of Cryosurgery on Pancreatic Cancer, International Society of Cryosurgery, and Asian Society of Cryosurgery. Pancreas. 2017 Sep;46(8):967-72. doi: 10.1097/ MPA.0000000000000878.

4. Dronov AI, Kovalskaya IA, Zemskov SV, Bakunets PP, Dobush RD, Kozachuk YeS, Khomenko DI. Opyt primenenija kriohirurgicheskogo metoda v kompleksnom lechenii pacientov z ochagovoj patologiej pecheni. Hirurgija. Vostochnaja Evropa. 2018;7(1):8-12. [In Russian].

5. Dronov OI, Khomenko DI, Bakunets PP, Teteryna VV. Temperature changes during cryoeffect potentiated with distilled water assessed in porcine liver model without splanchnic blood flow. Probl Cryobiol Cryomed, 2017;27(4):348-55. doi: 10.15407/cryo27.04. [In Ukrainian]

6. Dronov AI, Kovalskaya IA, Khomenko DI, Zharkov AY, Leshchenko VM, Krutko OA, Kozachuk YeS. Termometrija processa lokal'nogo kriovozdejstvija $v$ biologicheskoj tkani na diskretnyh glubinah: razrabotka kompleksa izmeritel'nogo intraoperacionnogo termoparnogo chetyrehkanal'nogo (KIIT-4). Hirurgija. Vostochnaja Cvropa. 2018;7(1):217. [In Russian].

7. Shafranov VV, Borkhunova EN, Kostylev MA, Tsyganov DI, Torba AM, Taganov AV, Mezhov LP, Kalmykova ZV. Mehanizmy razrushenija biologicheskih tkanej pri lokal'nom kriovozdejstvii.Vestnik RAEN 2012;(1):68-77. [In Russian]. 